\title{
Natural medicaments in endodontics - a comparative study of the anti-inflammatory action
}

\section{Medicamentos naturais na Endodontia - estudo comparativo da ação antiinflamatória}

Fabiane Bortoluci da Silva*

Juliano Milanezi de Almeida**

Simone Maria Galvão de Sousa***

\begin{abstract}
The objective of this study was to evaluate the irritant potential of propolis, Casearia sylvestris, Otosporin and saline solution (control). Twenty-eight male Wistar rats were selected, anesthetized and four experimental sites were designed on their backs. Injections of $2 \%$ Evans blue were intravenously administered in the lateral caudal vein and $0.1 \mathrm{ml}$ of the tested solutions was injected intradermally into the experimental sites. The animals were killed 1/2, 1, 3 and 6 hours after the injection of the solutions. Each piece of skin containing the lesion was immersed in formamide and incubated at $45^{\circ} \mathrm{C}$ for $72 \mathrm{~h}$. After filtration, optical density was measured in a spectrophotometer. Data were statistically analyzed by a 2-way non-parametric test. The highest values of extracted dye were observed at 3 hours characterizing a peak in the inflammatory process. Propolis was the least irritant solution. The natural medicaments tested in this study may be a valuable alternative for endodontic treatment.
\end{abstract}

DESCRIPTORS: Endodontics; Dental pulp cavity; Naturopathy; Anti-inflammatory agents.

RESUMO: O objetivo desta pesquisa foi avaliar o potencial irritativo de própolis, Casearia sylvestris, Otosporin e soro fisiológico (controle). Foram utilizados 28 ratos machos da linhagem Wistar. Os animais foram anestesiados e, em seguida, receberam a injeção do corante azul de Evans $(2 \%)$ por via intravenosa na veia caudal. Em quatro pontos predeterminados e depilados da região dorsal de cada animal, foram injetados $0,1 \mathrm{ml}$ das substâncias teste. Os animais foram sacrificados meia, uma, três e seis horas após a injeção das substâncias, e cada pedaço de pele contendo a lesão foi colocado em frascos contendo formamida, que foram incubados a $45^{\circ} \mathrm{C}$ por $72 \mathrm{~h}$. Após esse periodo, as amostras foram filtradas e submetidas à análise em espectrofotômetro. Os dados foram submetidos ao teste estatístico não-paramétrico de medidas repetidas. No periodo de $3 \mathrm{~h}$, foram observados os maiores valores de corante extraído, caracterizando, assim, o pico do processo inflamatório. A própolis foi a substância que apresentou menor potencial irritativo. Os produtos naturais testados neste trabalho podem ser uma alternativa para o tratamento endodôntico.

DESCRITORES: Endodontia; Cavidade da polpa dentária; Naturopatia; Antiinflamatórios.

\section{INTRODUCTION}

Microbial, mechanical or chemical irritation of the pulp and periradicular tissues lead to inflammation. In cases of vital pulp therapy that requires placement of an intracanal medicament between appointments, the choice of this agent depends on its biological characteristics: non-irritant, pulp vitality preservation, control of intensity and duration of inflammatory processes and infection, and potential healing induction ${ }^{9,12}$.

Several chemicals and therapeutic agents have been suggested as intracanal medicaments. The most commonly employed are calcium hydroxide and the combination of steroid and antibiotic ${ }^{12}$. Otosporin (Zest, Rio de Janeiro, RJ, Brazil) reduces vasodilatation, decreases liquid exudation, and also presents a direct vasoconstrictive action on small blood vessels ${ }^{9}$. Holland et al. ${ }^{13}$ (1980) compared three commercially prepared corticosteroidantibiotic solutions after pulpectomy and biomechanical preparation in dogs' teeth. Otosporin was more effective as an intracanal medication than Panotil and Otosynalar.

* Biologist, Specialist in Sciences, Center of Biological Sciences and Professions of Health; *** Professor of Oral Pathology, School

of Dentistry - University of Sacred Heart, Bauru.

** Postgraduate in Periodontology, School of Dentistry of Araçatuba, São Paulo State University. 
Silva FB, Almeida JM, Sousa SMG. Natural medicaments in endodontics - a comparative study of the anti-inflammatory action. Braz Oral Res 2004;18(2):174-9.

Medicinal plants constitute a promising source of phytotherapy drugs and new molecules. The number of studies on this alternative therapeutic system increased in the last decades, as well as their use for several purposes ${ }^{7}$.

Casearia sylvestris is a medicinal plant that offers a wide range of uses: healing, antiseptic, antiulcerative, diuretic, tonic, stimulant, antimicrobial, and depurative. This species is very common in the tropical America and Brazil; one of its popular names is "guacatonga" ${ }^{20}$.

Studies have demonstrated controversial results about its anti-inflammatory action. Ruppelt et al. ${ }^{18}$ (1991) analyzed the analgesic and anti-inflammatory action of 10 plants similar to C. sylvestris by means of Evans blue diffusion in the peritoneal cavity, and observed reduced activity for C. sylvestris. Furthermore, another study indicated that the alcoholic extract of $C$. sylvestris prolonged the acute phase of the inflammatory process ${ }^{5}$. The C. sylvestris extract constitutes a rich source of phospholipase $\mathrm{A}_{2}$ inhibitors. The components of this plant inhibit the enzymatic and toxic activities of several venoms, are effective in inhibiting isolated class I and II phospholipases $\mathrm{A}_{2}$, and the extract is partially effective against edema formation $^{3}$. A clinical investigation demonstrated progressive healing of intra and extraoral lesions of herpes simplex after topic application of C. sylvestris extract ${ }^{4}$.

Propolis is a resin widely used in folk medicine for centuries. The chemical composition of this atoxic natural substance is complex. Flavonoids and cinnamic acid derivatives have been considered as the main primary biologically active components ${ }^{10,14,16}$. It is known that propolis exhibits several pharmacological properties such as antimicrobial, anti-inflammatory, healing, anesthetic, cytostatic and cariostatic properties. Ethanolic extract of propolis inhibits hyaluronidase activity. This enzyme is responsible for several inflammatory processes and, if a certain substance is able to inhibit its activity, such substance will have a great potential as an anti-inflammatory agent ${ }^{17}$. In Dentistry, propolis has been used for the treatment of aphthous ulcers, Candida albicans, acute necrotizing ulcerative gingivitis (ANUG), gingivitis and periodontitis $8,10,15,16$.

The method proposed by Udaka et al. ${ }^{21}$ (1970) has often been employed in an attempt to quantify the irritant potential of several substances injected intradermally (or inoculated in vivo) and also to evaluate the effectiveness of anti-inflammatory drugs. This method analyzes the plasma exudate produced after an increase in vascular permeability that can be inferred by means of spectrophotometric measurement of Evans blue dye.

The purpose of this study was to comparatively evaluate the biocompatibility of propolis, Casearia sylvestris, Otosporin and saline solution (control) using the physicochemical method for quantification of the enhanced vascular permeability (Evans blue test).

\section{MATERIALS AND METHODS}

Twenty-eight adult male Wistar rats (Rattus norvegicus) weighting approximately $320 \mathrm{~g}$ were used. The rats were anesthetized with an association of ketamine (Francotar, Virbac do Brasil Indústria e Comércio Ltda., São Paulo, Brazil) and xylazine (Virbaxyl 2\%, Virbac do Brasil Indústria e Comércio Ltda., São Paulo, Brazil). Their backs were shaved and four experimental sites were designated. Their tails were washed and dried in order to facilitate the injection of $2 \%$ Evans blue $(20 \mathrm{mg} /$ kg; Merck, Darmstadt, Germany), administered intravenously in the lateral caudal vein.

Immediately after this, $0.1 \mathrm{ml}$ of each tested solution - propolis $(10 \%$ alcoholic solution; Propovit, Bionatus Laboratório Botânico Ltda., São José do Rio Preto, Brazil), aqueous/alcoholic extract of Brazilian Casearia sylvestris (10 g of fresh plant in $100 \mathrm{ml}$ of alcohol, Extratoline 115, A Natureza Produtos Farmacêuticos Ltda., Brazil), Otosporin (Zest Pharmaceutics Ltda., Rio de Janeiro, Brazil) and saline solution (0.9\% NaCl, Darrow Laboratório S/A, Rio de Janeiro, Brazil) - was injected intradermally into the experimental sites following a rotational system. Both natural medicaments were prepared by dissolving $1 \mathrm{ml}$ of the drug in $9 \mathrm{ml}$ of distilled water.

Evaluation of the inflammatory exudate was performed after 1/2, 1, 3 and 6 hours. Subsequently, subgroups were established in each group according to the period of time elapsed before sacrifice. After the determined period, the animals were killed by injecting an excessive dose of anesthetic (100 mg/kg). Dorsal skin was dissected and skin lesions were punched out with a standard steel punch set (3 $\mathrm{cm}$ in diameter). Each piece of skin containing the lesion was cut into small pieces and the dye was extracted with $10 \mathrm{ml}$ of formamide (Vetec Química Fina Ltda, Rio de Janeiro, Brazil) for 72 hours at $45^{\circ} \mathrm{C}$. 
Silva FB, Almeida JM, Sousa SMG. Natural medicaments in endodontics - a comparative study of the anti-inflammatory action.

Braz Oral Res 2004;18(2):174-9.

Optical density was measured after filtration with glass wool. Initially, the curve of the absorption spectrum of Evans blue was determined to achieve the best wavelength and calibration curve for the Evans blue. Measures were made at $620 \mu \mathrm{m}$ $\left(\mathrm{A}^{620}\right)$ in a spectrophotometer (Ultrospec 2000, Pharmacia Biotech, Cambridge, USA). Transformation of each sample or group mean absorption, in $\mu \mathrm{g}$, was obtained using the formula: $\mu \mathrm{g}=\mathrm{ab}$ sorption $\times$ calculation factor $(68) \times$ total volume of formamide. Data were statistically analyzed by a 2-way non-parametric test (Friedman Repeated Measures Analysis of Variance on Ranks).

\section{RESULTS}

The means and standard deviations of the amount of dye extracted $(\mu \mathrm{g})$ for all experimental groups are presented in Table 1. Medians and semi-interquartile range of the amount of dye extracted $\left(\mathrm{A}^{620}\right)$ and the respective results of the non-parametric statistical test comparing time and substance are expressed in Table 2.

Graph 1 illustrates the medians of the amount of dye extracted ( $\mu \mathrm{g})$ for all experimental groups, showing an enhanced vascular permeability at the 3-hour experimental period.

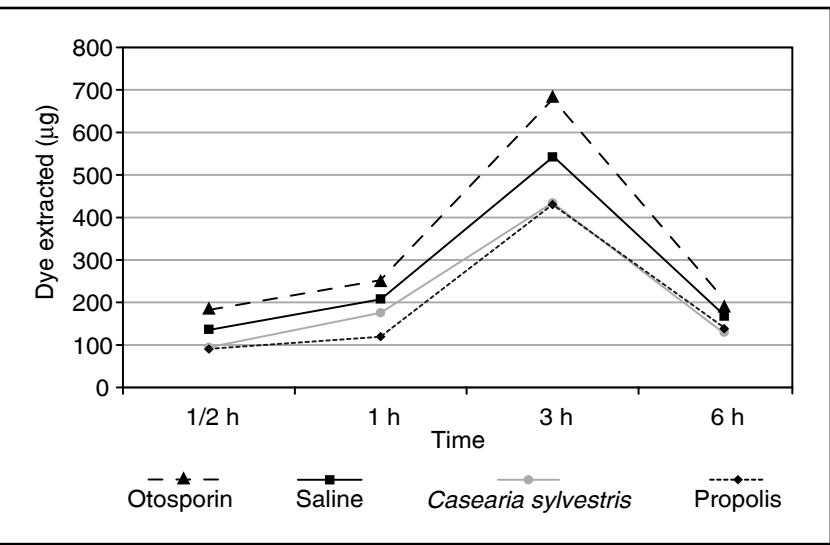

GRAPH 1 - Medians of the quantification of dye extracted $(\mu \mathrm{g})$ from the experimental groups along time.

TABLE 1 - Means and standard deviations (SD) of the amount of dye extracted ( $\mu$ g) in each experimental group, as to substance and time.

\begin{tabular}{c|c|c|c|c|c|c|c|c}
\hline \hline \multirow{2}{*}{ Time } & \multicolumn{9}{|c}{ Substance } \\
\cline { 2 - 9 } & \multicolumn{2}{|c|}{ Propolis } & Casearia sylvestris & \multicolumn{2}{c}{ Otosporin } & \multicolumn{2}{c}{ Saline solution } \\
\cline { 2 - 9 } & Mean & SD & Mean & SD & Mean & SD & Mean & SD \\
\hline $1 / 2 \mathrm{~h}$ & 100.17 & 51.94 & 127.55 & 39.20 & 443.82 & 154.77 & 181.60 & 96.21 \\
\hline $1 \mathrm{~h}$ & 105.35 & 22.85 & 189.07 & 33.49 & 496.10 & 197.37 & 132.62 & 33.12 \\
\hline $3 \mathrm{~h}$ & 175.62 & 37.97 & 297.00 & 108.92 & 641.16 & 383.27 & 199.26 & 35.81 \\
\hline $6 \mathrm{~h}$ & 162.81 & 55.34 & 212.51 & 29.58 & 630.54 & 334.63 & 204.02 & 90.28 \\
\hline \hline
\end{tabular}

TABLE 2 - Medians, semi-interquartile range and minimum and maximum values of absorption of the dye extracted $\left(\mathrm{A}^{620}\right)$ as to substance and time.

\begin{tabular}{|c|c|c|c|c|c|}
\hline \multirow{2}{*}{ Substance } & \multicolumn{4}{|c|}{ Time } & \multirow{2}{*}{$\begin{array}{l}\text { Result - } \\
\text { test of time }\end{array}$} \\
\hline & $1 / 2 \mathrm{~h}$ & $1 \mathrm{~h}$ & $3 \mathrm{~h}$ & $6 \mathrm{~h}$ & \\
\hline Propolis & $\begin{array}{c}90.10 \pm 15.00 \\
(60.32 ; 213.18) \mathrm{aA}\end{array}$ & $\begin{array}{c}119.54 \pm 26.12 \\
(83.57 ; 197.47) \mathrm{aB}\end{array}$ & $\begin{array}{c}430.10 \pm 94.98 \\
(266.90 ; 726.78) \mathrm{aC}\end{array}$ & $\begin{array}{c}137.97 \pm 84.04 \\
(92.07 ; 324.09) \mathrm{aB}\end{array}$ & $\begin{array}{c}16.20 \\
(\mathrm{p}<0.01)\end{array}$ \\
\hline $\begin{array}{l}\text { Casearia } \\
\text { sylvestris }\end{array}$ & $\begin{array}{c}94.59 \pm 13.35 \\
(82.69 ; 148.24) \mathrm{abA}\end{array}$ & $\begin{array}{c}175.44 \pm 19.29 \\
(148.92 ; 247.32) \mathrm{abB}\end{array}$ & $\begin{array}{c}434.18 \pm 151.71 \\
(282.47 ; 824.02) \mathrm{aC}\end{array}$ & $\begin{array}{c}129.95 \pm 26.54 \\
(90.03 ; 181.20) \mathrm{aA}\end{array}$ & $\begin{array}{c}17.91 \\
(\mathrm{p}<0.01)\end{array}$ \\
\hline Otosporin & $\begin{array}{c}186.66 \pm 23.75 \\
(102.54 ; 209.17) \mathrm{cA}\end{array}$ & $\begin{array}{c}258.67 \pm 68.33 \\
(110.02 ; 412.28) \mathrm{bB}\end{array}$ & $\begin{array}{c}685.44 \pm 260.43 \\
(49.98 ; 1,188.64) \mathrm{aB}\end{array}$ & $\begin{array}{c}191.62 \pm 23.78 \\
(162.18 ; 263.23) \mathrm{aA}\end{array}$ & $\begin{array}{c}9.34 \\
(\mathrm{p}<0.05)\end{array}$ \\
\hline $\begin{array}{l}\text { Saline } \\
\text { solution }\end{array}$ & $\begin{array}{c}136.61 \pm 36.08 \\
(117.37 ; 258.67) \mathrm{bcA}\end{array}$ & $\begin{array}{c}208.15 \pm 23.27 \\
(166.53 ; 246.70) \mathrm{bA}\end{array}$ & $\begin{array}{c}542.16 \pm 116.39 \\
(379.37 ; 1,351.9) \mathrm{aB}\end{array}$ & $\begin{array}{c}167.55 \pm 67.30 \\
(131.10 ; 355.50) \mathrm{aA}\end{array}$ & $\begin{array}{c}14.14 \\
(\mathrm{p}<0.01)\end{array}$ \\
\hline $\begin{array}{l}\text { Result - test } \\
\text { of substance }\end{array}$ & $12.94(\mathrm{p}<0.01)$ & $15.08(\mathrm{p}<0.01)$ & $2.93(\mathrm{p}>0.05)$ & $7.32(\mathrm{p}>0.05)$ & \\
\hline
\end{tabular}

Two medians followed by a same lower case letter do not differ $(\mathrm{p}>0.05)$ regarding the substances at a given period. Two medians followed by a same capital letter do not differ $(p>0.05)$ regarding periods of time for the same substance. 
Silva FB, Almeida JM, Sousa SMG. Natural medicaments in endodontics - a comparative study of the anti-inflammatory action. Braz Oral Res 2004;18(2):174-9.

All substances tested showed exudation of the Evans blue dye, and the intensity varied according to the substance tested. There was no statistically significant difference between all tested substances at 3 and 6 hours $(p>0.05)$. There was a statistical difference at $1 / 2$ and 1 hour between propolis and Casearia sylvestris extracts and the other substances $(\mathrm{p}<0.01)$. However, there was no significant difference between the extracts. After 6 hours, there was a decrease in the amount of dye extracted, with almost no significant difference compared to the $1 / 2$-hour values. Otosporin had the greatest exudation at $1 / 2$ and 1 hour $(p<0.01)$. Analyses of the medians of all groups considering their semi-interquartile range values indicated that propolis presented the lowest inflammatory exudate, followed by Casearia sylvestris extracts.

\section{DISCUSSION}

Although it has been recognized that the use of intracanal medications is controversial, these have been demonstrated to be useful and beneficial in some clinical conditions. These medicaments have been proposed for disinfection of the root canal by means of an antibacterial agent by reducing and controlling pulp and periapical inflammatory reactions; inducing the healing process; and controlling, preventing or reducing post-treatment pain and discomfort.

As stated by Holland et al. ${ }^{13}$ (1980), Otosporin presented the best results when compared with other commercially prepared corticosteroid-antibiotic products, Panotil and Otosynalar. In this study, Otosporin showed to be less effective as an anti-inflammatory drug. Comparing the results of this research with the literature available $e^{2,3,5,8,13,15,17}$, the natural products - propolis and Casearia sylvestris extracts - seem to be a valid alternative as a short-term intracanal medication in cases of pulp and periapical inflammatory processes.

There is still controversy about the action of Casearia sylvestris due to its different forms available, combinations, $\mathrm{pH}$, and dilution type of extracts. Clinical studies initially verified that undiluted alcoholic extract of Casearia sylvestris ( $\mathrm{pH}$ 5.68) prolonged the acute phase of the inflammatory process, delaying the events of the regenerative phase. Subsequently, the same methodology demonstrated that buffered and diluted alcoholic extracts of Casearia sylvestris ( $\mathrm{pH} 7.18)$ reduced the acute phase of the inflammatory process, in addition to intensifying and prolonging the regenerative phase ${ }^{6}$.

The anti-inflammatory effect of Casearia sylvestris is related to its dose. A dose of $300 \mathrm{mg} / \mathrm{kg}$ is required to provide a good action. A significant inhibition of the Ehrlich solid tumor growth has also been demonstrated, suggesting an anti-proliferative action. These findings characterize the antiinflammatory and anti-tumoral effect of Casearia sylvestris in specific doses ${ }^{2}$.

Our results are in agreement with Borges et $a .^{3}$ (2000), who observed lower irritant potential with Casearia sylvestris. This might be explained by the capacity to inhibit phospholipase $A_{2}$ and consequently the inflammatory process. However, Otosporin, which is a steroid anti-inflammatory agent that inhibits phospholipase $\mathrm{A}_{2}$, was not as effective as the Casearia sylvestris extract.

Nevertheless, propolis showed to be more effective than the other drugs for reduction of the acute anti-inflammatory exudate. This finding confirms its anti-inflammatory activity, as mentioned in previous studies. The events attributed to the application of $5 \%$ ethanolic extracts of propolis in the dental cavity of dogs were reduction of the anti-inflammatory reaction, positive performance as to tissue reorganization in the superficial level, as well as antibacterial activity ${ }^{16,19}$. In the beginning of the Greek civilization, Aristotle observed that propolis had the ability to defend a city with thousands of inhabitants, the beehive. This defense exists for both the architectural structural repair of the beehive and maintenance of the species, preparing aseptic places for laying off the eggs of the queen bee ${ }^{10}$.

Concerning the methodology, it showed to be effective for the evaluation of the anti-inflammatory activity of several medications such as non-steroidal anti-inflammatory drugs ${ }^{1,11}$. Vascular permeability alterations can be demonstrated through intravenous injection of vital dyes. The vital dye bonds with plasma albumin to form a proteinbound dye complex, which is suitable as a plasma marker for the detection of protein leakage in an area of edema.

The peak of the inflammatory process occurs after 3 hours, gradually decreasing with time. The higher period of antiexudative activity is observed after 1 hour (early permeability phase). The most sensitive phase of the acute inflammation to the substances tested was at 3 hours (late permeability phase). Considering that prostaglandins are the mediators of the late phase of the inflamma- 
Silva FB, Almeida JM, Sousa SMG. Natural medicaments in endodontics - a comparative study of the anti-inflammatory action. Braz Oral Res 2004;18(2):174-9.

tory process, it is possible to understand that the substances used in this study do not inhibit the biosynthesis of prostaglandins and consequently do not effectively act in this phase. All solutions tested were time-dependent.

Currently, the development and accessibility of information on phytopharmaceuticals and natural medications are gradually gaining the respect of some patients and health professionals. Besides, the exploitation of these substances has a socioeconomic impact. It leads to an increase in cultivation fields and in the market of informal herbs and beekeepers, as well as in an expansion of small and medium national pharmaceutical laboratories dedicated to manufacturing medicaments of natural and vegetable origin.

\section{CONCLUSIONS}

According to the methodology of this preliminary study, the natural medicaments propolis and

\section{REFERENCES}

1. Akatsu T, Catanzaro Guimarães SA. Comparative effects of non-steroidal anti-inflammatory drugs, mefenamic acid, metiazinic acid and glucametacin on the inflammatory response induced by subcutaneous implantation of human dental plaque and on the mitotic activity of isoproterenol-stimulated parotid glands of rats. Cell Mol Biol 1986;32:619-26.

2. Almeida A. Atividades antiinflamatória e antitumoral do extrato hidroalcoólico de Casearia sylvestris: estudo comparativo com os antiinflamatórios piroxicam e meloxicam [Tese de Mestrado]. São Paulo: Instituto de Ciências Biomédicas da USP; 2000.

3. Borges MH, Soares AM, Rodrigues VM, Andrião-Escarso $\mathrm{SH}$, Diniz H, Hamaguchi A, et al. Effects of aqueous extract of Casearia sylvestris (Flacourtiaceae) on action of snake and bee venoms and on activity of phospholipases $A_{2}$. Comp Biochem Physiol B Biochem Mol Biol 2000;127:21-30.

4. Camargo FG, Gomes E, Pannunzio E, Bueno VS. Uso tópico de extrato fluido de folha de guaçatonga (Casearia sylvestris Swartz) topicamente em lesões de estomatite herpética. LECTA - USF Brag Pta 1993;1:121-7.

5. Camargo FG, Pereira JA, Bueno VS, Gomes E, Ando T. Ação do extrato alcoólico de guaçatonga (Casearia sylvestris sw) em subcutâneo de camundongo. Parte I. Estudo histológico. LECTA-USF 1995;13:47-68.

6. Camargo FG, Pereira JA, Bueno VS, Gomes E, Ando T. Ação do extrato alcoólico de guaçatonga diluído e tamponado em subcutâneo de camundongo. Parte II. Estudo histológico. LECTA-USF 1996;14:61-86.

7. di Stasi LC. Plantas medicinais: arte e ciência; um guia de estudo. São Paulo: UNESP; 1996.

8. Duarte S, Koo H, Bowen WH, Hayacibara MF, Cury JA, Ikegaki $\mathrm{M}$, et al. Effect of a novel type of propolis and its chemical fractions on glucosyltransferases and on growth
Brazilian Casearia sylvestris extracts may offer a good alternative as short-term intracanal medicaments. Our results indicated that propolis presented the lowest value of inflammatory exudate, followed by Casearia sylvestris extract. However, this study did not allow the establishment of the nature of the bioactive compound(s) responsible for the anti-inflammatory activity. Further chemical and pharmacological investigations in animal models using different dilutions and $\mathrm{pH}$ values are under way in an attempt to better identify their effectiveness and clinical applicability.

\section{ACKNOWLEDGEMENT}

The authors would like to thank Carlos Roberto Padovani for the statistical analysis and Thelma Lopes Silva for her technical assistance.

and adherence of mutans streptococci. Biol Pharm Bull 2003;26:527-31.

9. Fava LRG. Human pulpectomy: incidence of postoperative pain using two different intracanal dressings. Int Endod J 1992;25:257-60.

10. Geraldini CAC, Salgado EGC, Rode SM. Ação de diferentes soluções de própolis na superficie dentinária - avaliação ultra-estrutural. RPG Rev Pos Grad 2000;3:37-42.

11. Guimarães SA, Akatsu T, Tago EM, Consolaro A. Assessment of the antiexudative and antiproliferative activities of non-steroidal anti-inflammatory drugs in inflammatory models developed in rats by subcutaneous implantation of bacterial cell walls from the dental plaque. Inflammation 1996;20:623-36.

12. Hidalgo MM, Kawana GRC, Gonçalves CEB, Oliveira RMMW, Bersani-Amado CA. Avaliação da tolerância tecidual a algumas substâncias utilizadas como curativo de demora no tratamento endodôntico. Rev Fac Odontol Lins 1999;11:5-9.

13. Holland R, Souza V, Nery MJ. Emprego da associação corticosteróide-antibiótico durante o tratamento endodôntico. Rev Paul Endod 1980;2:4-7.

14. Koo H, Gomes BPFA, Rosalen PL, Ambrosano GMB, Park YK, Cury JA. In vitro antimicrobial activity of propolis and Arnica montana against oral pathogens. Arch Oral Biol 2000;45:141-8.

15. Magro Filho O, de Carvalho ACP. Application of propolis to dental sockets and skin wounds. J Nihon Univ Sch Dent 1990;32:4-13.

16. Manara LRB, Anconi SI, Gromatzky A, Conde MC, Bretz WA. Utilização da própolis em Odontologia. Rev FOB 1999;7:15-20.

17. Park YK, Ikegaki M, Alencar SM. Classificação das própolis brasileiras a partir de suas características fisico- 
Silva FB, Almeida JM, Sousa SMG. Natural medicaments in endodontics - a comparative study of the anti-inflammatory action. Braz Oral Res 2004;18(2):174-9.

químicas e propriedades biológicas. [periódico online] 2002. Disponivel em: URL: http://www.naturapi.com.br/artigo. htm.

18. Ruppelt BM, Pereira EFR, Gonçalves LC, Pereira NA. Pharmacological screening of plants recommended by folk medicine as anti-snake venom - I. Analgesic and anti-inflammatory activities. Mem Inst Oswaldo Cruz 1991;86:203-5.

19. Scheller S, Ilewicz L, Luciak M, Skrobidurska D, Stojko A, Matuga W, et al. Biological properties and clinical application of propolis. IX. Experimental observation on the influence of ethanol extract of propolis (EEP) on dental pulp regeneration. Arzneimittelforschung 1978;28:289-91.

20. Teske M, Trentini AMM. Herbarium - Compêndio de Fitoterapia. $3^{a}$ ed. Curitiba: Herbarium Laboratório Botânico; 1995

21. Udaka K, Takeuchi Y, Movat HZ. Simple method for quantitation of enhanced vascular permeability. Proc Soc Exp Biol Med 1970;133:1384-7.

Received for publication on Nov 12, 2003

Sent for alterations on Mar 29, 2004

Accepted for publication on May 05, 2004 